\title{
Potential use of Sorghum bicolor and Carthamus tinctorius in phytoremediation of nickel, lead and zinc
}

\author{
Z. Al Chami ${ }^{1}$ N. Amer ${ }^{2,3} \cdot$ L. Al Bitar ${ }^{1}$ I. Cavoski ${ }^{1}$
}

Received: 7 July 2014/Revised: 18 March 2015/Accepted: 25 April 2015/Published online: 13 May 2015

(C) Islamic Azad University (IAU) 2015

\begin{abstract}
Metals are very common contaminants in the soil. High-yielding biomass crops offer good potential for the phytoremediation of soils contaminated with heavy metals. Biomass fuel crops grown on contaminated land have several advantages as site remediation combined with bioenergy production. In this context, two energy crops, Sorghum bicolor and Carthamus tinctorius, were grown hydroponically to assess their potential use in phytoremediation of nickel $(\mathrm{Ni})$, lead $(\mathrm{Pb})$ and zinc $(\mathrm{Zn})$ and biomass production. The experiment was carried out in a growth chamber using half-strength Hoagland's solution spiked separately with five concentrations for $\mathrm{Ni}, \mathrm{Pb}$ and $\mathrm{Zn}$ (between 5 and $100 \mathrm{mg} \mathrm{L}^{-1}$ ). Shoot and root biomass were determined and analyzed for their metals contents. Results showed that the tested plants were able to uptake $\mathrm{Ni}, \mathrm{Pb}$ and $\mathrm{Zn}$. Furthermore, roots accumulated more metals than shoots. Ni seems to be more toxic than $\mathrm{Zn}$ and $\mathrm{Pb}$. In fact, both species were unable to grow at Ni concentration above $10 \mathrm{mg} \mathrm{L}^{-1}$. Metal toxicity ranked as follows: $\mathrm{Ni}>\mathrm{Zn}>\mathrm{Pb}$. High toxicity symptoms and biomass reduction were observed at concentrations of $\mathrm{Pb}$ and $\mathrm{Zn}$ above $25 \mathrm{mg} \mathrm{L}^{-1}$ for both species. S. bicolor was more efficient than $C$. tinctorius in metal uptake due to the high biomass production and the relatively high shoot
\end{abstract}

\section{Z. Al Chami}

alchami@iamb.it

1 CIHEAM - Mediterranean Agronomic Institute of Bari (IAM-Bari), Via Ceglie 9, 70010 Valenzano, Italy

2 Dipartimento di Scienze per l'Ambiente, Università degli Studi di Napoli "Parthenope", Via F. Acton, 38, 80133 Naples, Italy

3 Swaida Research Center, General Commission for Scientific Agricultural Research - GCSAR, Swaida, Syria concentration of metal. S. bicolor could be successfully used in phytoremediation applications in marginal soils with moderately heavy metal contamination. However, results obtained through the hydroponic experiment need to be confirmed by field experiments.

Keywords Biomass - Energy crops - Heavy metals · Hydroponics $\cdot$ S. bicolor $\cdot$ C. tinctorius

\section{Introduction}

Heavy metals are very common contaminants in the environment. The adverse environmental impacts from excessive heavy metals include contamination of water and soil, phytotoxicity, soil degradation and pose serious risks to human health (Adriano 2001). Their negative impacts on the environments are causing increasing concern in scientists, politicians and general public worldwide.

Current remediation techniques of heavy metals are classified in biological (biodegradation by living organisms), chemical (chelators, chemical immobilization, oxidation, etc.) and physical (electrokinetic remediation, incineration technologies, soil washing, stabilization/solidification, thermal desorption, etc.) remediation techniques (Hamby 1996). However, all of them are expensive, time-consuming and environmentally destructive. Therefore, effective cleanup requires their removal/immobilization to reduce or remove toxicity (Henry 2000).

In recent years, scientists generated cost-effective technologies, including the use of immobilizing soil amendments such as compost (Al Chami et al. 2013), biochar (Hmid et al. 2014), bagasse fly ash (Gupta and Ali 2004; Gupta et al. 2003; (Gupta and Ali 2000) and/or plants to clean polluted areas. Various additives were applied as soil 
amendments to reduce metal plant uptake (Vangronsveld et al. 2009).

Phytoremediation is the direct use of living plants for in situ remediation of contaminated soil, sludges, sediments and groundwater through contaminant removal, degradation or containment (EPA 1999). Phytoremediation is an emerging technology for cleaning up contaminated sites. It is cost-effective and offers esthetic advantages and long-term applicability. The main phytoremediation techniques implemented for heavy metal-contaminated land are phytostabilization and phytoextraction. Phytostabilization is applied by using root-accumulating plants in order to reduce the mobility or bioavailability of metals, which are stabilized in the substrate and/or accumulated in root tissue (Salt et al. 1995). Phytoextraction is a method of using plants with high shoot-accumulation ability to extract metals from soils/sediments/water, and it has been demonstrated to be an economically feasible method of treating polluted land (Fritioff and Greger 2003). Many plant species were tested for their ability to accumulate toxic metals to high extent in the aboveground biomass. Most hyperaccumulator plants, such as Thlaspi caerulescens or Alyssum bertolonii, are characterized by slow growth and low biomass production, which make them less effective for use in phytoextraction in the field. For this reason, more recent research projects on phytoextraction have focused on high biomass crop species (Luo et al. 2005). High biomass crop species are characterized by their lower ability to accumulate toxic metals, but the total uptake (TU) of elements is comparable to hyperaccumulating plants due to high yield of aboveground biomass. In this context, plants belonging to Brassica spp. seem to be more effective for removing $\mathrm{Zn}$ from the contaminated soil compared to $\mathrm{Zn}$ hyperaccumulator $T$. caerulescens producing one order lower amount of shoot biomass (Ebbs et al. 1997). Nicotiana tabacum accumulating predominantly $\mathrm{Cd}$ and $\mathrm{Cu}$, and Zea mays are considered effective plants because of their high production of aboveground biomass with a relatively high content of metals (Wenger et al. 2002). EPA recommendations (EPA 2000) include metal accumulator plants such as Z. mays, Sorghum bicolor and Medicago sativa among plants that are able to remove a greater amount of metals, but more research is necessary to verify it.

In addition to the above-mentioned environmental threat caused by heavy metal contamination, recently, another problem has arisen: the fossil fuels use and the consequent greenhouse gas emission. The European energy policy promotes a gradual substitution of fossil fuels with renewable sources. This is motivated by increasing oil costs, the need to achieve partial energy independence, and the need to reduce greenhouse gas emissions. European countries are committed themselves to achieve, by 2020 , the following targets: cutting greenhouse gases emission by $20 \%$; reducing overall energy consumption by $20 \%$ through increased energy efficiency; meeting $20 \%$ of energy needs from renewable resources (EU 2008). In this context, the use of biomass feedstock from agricultural sources for bioenergy production might play a key role. Growing crops for bioenergy production has often been criticized as it would compete with food crops. Bioenergy can affect food security both positively and negatively. Nevertheless, the success of phytoextraction combined with bioenergy production depends upon the identification of suitable plant species that hyperaccumulate heavy metals and produce large amounts of biomass (Begonia et al. 1998; Clemens et al. 2002). Bioenergy crops grown on contaminated land offer real opportunities for stabilization, bioremediation and phytoremediation of heavy metalcontaminated soils. Bioenergy crops can remove heavy metals from soils and biomass produced can be used for fuel production. In addition, bioenergy crops grown on heavy metal-contaminated sites or marginal lands may provide additional income for land owners.

The full development of phytoremediation combined with bioenergy production needs a great deal of scientific work, which still remains to be done in the field of research and experimentation.

In this study, we investigated the possible use of two energy crops, S. bicolor and Carthamus tinctorius, grown hydroponically, coupling a good phytoremediation potential and biomass production for bioenergy purposes. These plants can provide a number of benefits such as: (1) optimal use of marginal land and industrial sites providing an economic advantage, (2) bioenergy production from renewable sources, (3) restoration of damaged land and reduction in the risk associated with heavy metal contamination and (4) economically advantageous cultivation of energy crops on contaminated lands.

Sorghum bicolor (sweet sorghum), belonging to the family Poaceae, is a hardy C4 grass widely used as a forage crop (Unger 2001), and it is considered as a great promising energy plant, due to its fast-growing and high biomass production. S. bicolor is relatively inexpensive to grow and gives high yields. Some studies showed that $S$. bicolor has the ability to accumulate heavy metals showing the greatest removal of $\mathrm{Pb}$ by leaves and the greatest removal of $\mathrm{Cd}$ and $\mathrm{Zn}$ by stems. Cropping of S. bicolor plants facilitated by agronomic practices may be a sustainable technique for partial decontamination of heavy metalcontaminated soils (Ping et al. 2009). S. bicolor can produce approximately 30 tons $\mathrm{ha}^{-1}$ year $^{-1}$ of dry biomass on low-quality soils with low inputs of fertilizer and limited water (Renewable Energy World 2000). In addition, it can be processed into various high value-added commodities, such as bio-ethanol, pyrolysis oil, electricity/heat, charcoal, 
hydrogen, activated coal, methanol and pulp for paper (Shoemaker and Bransby 2010). Cropping of S. bicolor plants facilitated by agronomic practices may be a sustainable technique for partial decontamination of heavy metal-contaminated soils (Zhuang et al. 2009). Contaminated biomass resulting from phytoremediation could be used for bioenergy production such us pyrolysis technology (Al Chami et al. 2014). In this context, contaminated biomass will be converted into energy and the remained biomass (char) will be reduced in weight and volume. This will allow us to add economic value to contaminated soils. C. tinctorius (safflower), an oilseed crop, belonging to the family Compositae. It is cultivated mainly for the production of edible oil. C. tinctorius is a highly branched, annual herbaceous plant, with a deep root system that enables it to draw water and nutrients from a considerable depth, conferring on it the ability to survive in areas with little surface moisture (Dajue and Mündel 1996). In addition, oil from $C$. tinctorus is considered to be a potential alternative fuel for diesel engines, thanks to its chemical and physical properties which are similar to those of commercial-grade diesel fuel (Dorado et al. 2004). Industrial processing will make $C$. tinctorius economically interesting crops for farmers of phytoremediation technology. C. ticnctorius is tolerant to metals, can be grown on contaminated soils and can be successfully used in the phytoremediation. It possesses interesting characteristics in terms of $\mathrm{Cd}$ accumulation. It has been reported that $C$. ticnctorius is capable of accumulating high levels of $\mathrm{Cd}$ in roots and leaves without showing symptoms of toxicity (Shi et al. 2010).

Hydroponic screening experiment using Hoagland's solution with a mixture of heavy metals can be suitable for the purposes of a rapid metal tolerance screening test and enables the differentiation between species and clones (Zacchini et al. 2009; Watson et al. 2003). Relative performance of the species tested hydroponically broadly corresponded to those observed in the field (Watson et al. 2003). Recently, many experiments were conducted using hydroponic experiment as a rapid plant screening test for metal tolerance and phytoremediation purposes (Amer et al. 2013). Hydroponic screening is a rapid test that could reflect the performance of the tested plant species in the field (Utmazian et al. 2007).

The main objective of this work is to evaluate the performance of two energy crops $S$. bicolor and $C$. tinctorius in heavy metal phytoremediation of low/moderate contamination, through a hydroponic study as rapid metal tolerance screening test. The heavy metals chosen for this work were $\mathrm{Pb}, \mathrm{Ni}$ and $\mathrm{Zn}$. Those metals are widely spread and are listed in the EU sewage sludge Council Directive (86/278/EEC) (1986) covers the almost entire legislation relating to soil contamination by heavy metals within the EU.

\section{Materials and methods}

\section{Plant materials, chemicals and growth conditions}

Seeds of S. bicolor were purchased from Syngenta Seeds S.A.S. (France) and C. tinctorius seeds from Nunhems S.A. (Paraje la Cumbre-Spain). Seeds were sterilized using $5 \%$ $\mathrm{NaOCl}(\mathrm{v} / \mathrm{v})$ for $5 \mathrm{~min}$, washed with distilled water and germinated over moistened filter papers with $2 \mathrm{~mL}$ distilled water in closed Petri dishes for $4-5$ days at $23{ }^{\circ} \mathrm{C}$, until the primary roots reached $4-5 \mathrm{~cm}$. Three uniform seedlings were then transferred to $300 \mathrm{~mL}$ glass bakers wrapped with aluminum papers to prevent evaporation, light penetration and algae growth. Glass bakers were filled with halfstrength Hoagland's nutrient solution (Millner and Kitt 1992). The composition of the nutrient solution was: $2.5 \mathrm{mM} \mathrm{Ca}\left(\mathrm{NO}_{3}\right)_{2} ; 2.5 \mathrm{mM} \mathrm{KNO}_{3} ; 1 \mathrm{~m} \mathrm{MMgSO}_{4} ; 0.2 \mu \mathrm{M}$ $\mathrm{KH}_{2} \mathrm{PO}_{4} ; 50 \mu \mathrm{M}$ NaFeEDTA; $0.2 \mu \mathrm{M} \mathrm{Na} \mathrm{MoO}_{4} ; 10 \mu \mathrm{M}$ $\mathrm{H}_{3} \mathrm{BO}_{3} ; 2 \mu \mathrm{M} \mathrm{MnCl}_{2} ; 0.5 \mu \mathrm{M} \mathrm{CuSO}_{4} ; 1.0 \mu \mathrm{M} \mathrm{ZnSO}_{4}$; and $0.2 \mu \mathrm{M} \mathrm{NiSO}$. The solution was buffered with $0.5 \mathrm{mM}$ MES (2-[N-morpholino]ethanesulfonic acid), adjusted to pH 6.0 and spiked with heavy metals. The nutrient solutions were replaced entirely twice a week to prevent nutrient and metal depletion.

The treatments were as follows: (a) control treatment (CTR), half-strength Hoagland's solution, (b) half-strength Hoagland's solution spiked with single metals in the following concentrations: $5,10,25,50$ and $100 \mathrm{mg} \mathrm{L}^{-1}$ for $\mathrm{Ni}, \mathrm{Pb}$ and $\mathrm{Zn}$. The treatments were identified by the chemical symbol of the metal followed by a number indicating the metal concentration in $\mathrm{mg} \mathrm{L}^{-1}$.

This experiment was conducted in a growth chamber (FDM mod. C1500S; F.lli Della Marca S.r.l.; Italy) with 16-h day and 8-h night photoperiod, a thermoperiod of 25 and $23{ }^{\circ} \mathrm{C}$, respectively, and relative humidity of $60 \%$ (day) and $70 \%$ (night).

Chemicals used for the nutrient solution [i.e., $\mathrm{Ca}\left(\mathrm{NO}_{3}\right)_{2}$, $\mathrm{KNO}_{3}, \mathrm{MgSO}_{4}, \mathrm{KH}_{2} \mathrm{PO}_{4}, \mathrm{NaFeEDTA}, \mathrm{Na}_{2} \mathrm{MoO}_{4}, \mathrm{H}_{3} \mathrm{BO}_{3}$, $\left.\mathrm{MnCl}_{2}, \mathrm{CuSO}_{4}, \mathrm{ZnSO}_{4}, \mathrm{NiSO}_{4}\right]$ were purchased from Sigma Aldrich (Germany). $\mathrm{PbNO}_{3}, \mathrm{NiSO}_{4} 6 \mathrm{H}_{2} \mathrm{O}$ and $\mathrm{ZnSO}_{4} .7 \mathrm{H}_{2} \mathrm{O}$ were supplied by MerckKgaA (Germany). Deionized water (Elix; Millipore Corporation) was used to prepare the plant nutrient solution. For sample mineralization and chemical analysis, $\mathrm{HNO}_{3}, \mathrm{H}_{2} \mathrm{O}_{2}$ TraceSelect and certified heavy metal standard solution were bought from Sigma Aldrich (Germany). Ultrapure water $\left(18.2 \mathrm{M} \Omega \mathrm{cm}^{-1}\right)$ was obtained with a Milli-Q purification system from Millipore (Bedford, MA, USA). 


\section{Determination of growth parameters and metal concentration}

$S$. bicolor and $C$. tinctorius were grown in the growth chamber on the metal-enriched nutrient solution for 30 days. Plants were then collected and separated into shoots and roots. Roots were exposed for $2 \mathrm{~h}$ to a solution of $0.05 \mathrm{M} \mathrm{CaCl}_{2}$ acidified at $\mathrm{pH} 3$ with $\mathrm{HCl}$ in order to remove adsorbed metals on root surface (Stolt et al. 2003). Roots were then washed repeatedly with distilled water. Shoot and root length were measured. Shoot and root dry weights were determined after incubation in an oven at $60{ }^{\circ} \mathrm{C}$ till constant weight was reached.

Dried plant materials were homogenized by means of Mixer Mill (MM 200-Retsch GmbH-Germany), and humidity at $105{ }^{\circ} \mathrm{C}$ was determined. Total heavy metals of the plant tissues were extracted by wet digestion of the dried sample $\left(1 \mathrm{~mL} \mathrm{H} \mathrm{O}_{2}\right.$ and $5 \mathrm{~mL} \mathrm{HNO}_{3}$ for $20 \mathrm{~min}$ at $190{ }^{\circ} \mathrm{C}$ ) using a microwave digester (CEM model, MARS Xpress). Samples were then filtered using a Whatman No. 42 filter paper, and the leachates were diluted (1:25) with ultrapure water. Metal content in the extracts was determined by inductively coupled plasma optical emission spectrometry (ICP-OES) (Thermo Electron ICAP 6300), after calibration with certified standard solutions. Total metal concentrations in plant tissues are expressed in mg kg ${ }^{-1}$ dry weight at $105^{\circ} \mathrm{C}$.

\section{Translocation factor and total uptake index}

Translocation factor (TF) is defined as the ratio of metal concentration in shoots to that in roots (McGrath and Zhao 2003) and is used to evaluate and quantify the translocation of heavy metals from roots to the harvestable aerial parts (Barman et al. 2000; Gupta et al. 2008). TU is defined as the product of metal concentration in shoots or roots $\left(\mu \mathrm{g} \mathrm{g}^{-1} \mathrm{dw}\right)$ and shoots or roots biomass $\left(\mathrm{g} \mathrm{plant}^{-1}\right)$ (Utmazian et al. 2007). The indexes were calculated according to the following equations:

1.

$\mathrm{TF}=\frac{\mu \mathrm{g} \text { metal } / \mathrm{g} \text { shoot } \mathrm{dw}}{\mu \mathrm{g} \text { metal } / \mathrm{g} \text { roots } \mathrm{dw}}$

2.

$\mathrm{TU}\left(\mu \mathrm{g}_{\mathrm{plant}}{ }^{-1}\right)=\mu \mathrm{g} \mathrm{metal}^{-1}$ shoots or roots $\mathrm{dw}$ $\times \mathrm{g}$ shoots or roots $\mathrm{dw}$ perplant

\section{Statistical analysis}

Complete randomized design with five replications for each treatment was adopted. Values are means of five measurements reported for each of the studied parameters.
One-way analysis of variance (ANOVA) was carried out, and separation of means was performed using LSD test at $P=0.05$ significance level. All statistics were computed using SAS software version 9 (SAS Institute, Cary, NC).

\section{Results and discussion}

\section{Growth performances}

Different response of S. bicolor and C. tinctorius to metal exposure was found, ranging from death, severe toxicity and biomass reduction to metal tolerance. The level of toxicity and biomass reduction as result of metal effect depended on metal type, metal concentration and plant species.

The visual symptoms of $\mathrm{Ni}, \mathrm{Pb}$ and $\mathrm{Zn}$ toxicity observed on $S$. bicolor and C. tincotorius shoots and roots are shown in Figs. 1 and 2. The plants at high metal concentration were stunted, growth was reduced, and leaves showed interveinal chlorosis or became dark red. At high metal concentration, roots exhibited blackening, blunting stunted growth and reduced biomass. Nickel was more toxic than $\mathrm{Pb}$ and $\mathrm{Zn}$ on the studied plant species. In fact, no growth was observed at $\mathrm{Ni}$ concentration above $10 \mathrm{mg} \mathrm{L}^{-1}$ for both species, while no growth was observed at $\mathrm{Pb}$ and $\mathrm{Zn}$ concentration above $50 \mathrm{mg} \mathrm{L}^{-1}$ on $S$. bicolor and above $25 \mathrm{mg} \mathrm{L}^{-1}$ on C. tinctorius.

Growth performance of S. bicolor and C. tincotorius as shoot and root dry weight (SDW and RDW), expressed both in $\mathrm{g} \mathrm{plant}^{-1}$ for SDW and in $\mathrm{cm}$ for shoot and root length (SL and RL) and both as percentage of the control, as affected by $\mathrm{Ni}, \mathrm{Pb}$ and $\mathrm{Zn}$ is shown in Table 1 . In most treatments, more inhibition was observed on roots than on shoots. Jadia and Fulekar (2008) reported that heavy metals are found to be more toxic for root growth because they accumulate on root and retard cell division and elongation. The greater impact of heavy metals was observed on the root growth as compared to shoot and led to greater reduction in plant length and weight (Elloumi et al. 2007).

Despite its toxicity, $\mathrm{Ni}$ at concentration of $5 \mathrm{mg} \mathrm{L}^{-1}$ seemed to have a slight stimulating effect on $S$. bicolor shoots. In fact, Ni5 treatment significantly increased $S$. bicolor SDW by $11 \%$ and SL by $20 \%$. Conversely, Ni5 treatment decreased $C$. tinctorius SDW and SL by 67 and $64 \%$, respectively. Ni5 and Ni10 treatments reduced root growth in both studied species. Ni seems more toxic than $\mathrm{Pb}$ and $\mathrm{Zn}$. In fact, the toxic effect of Ni was more pronounced and the plants were not able to grow at $\mathrm{Ni}$ concentration above $10 \mathrm{mg} \mathrm{L}^{-1}$. Severe toxicity symptoms and biomass reduction were observed in Ni10 treatments for both species. At the concentration $5 \mathrm{mg} \mathrm{L}^{-1}$, Ni has no effect on growth for S. bicolor, while a significant biomass reduction was observed for $C$. 


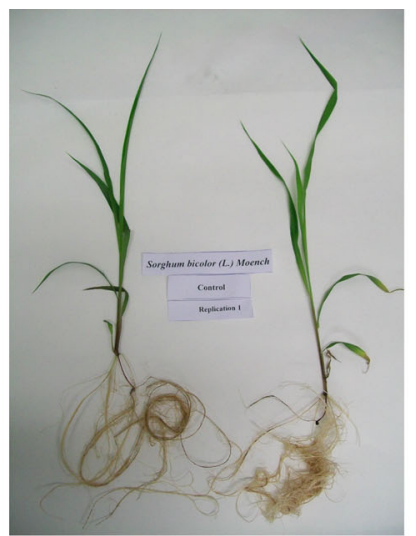

S. bicolor - CTR

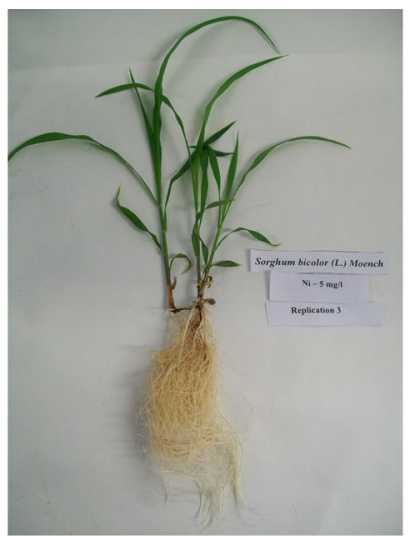

S. bicolor - Ni5

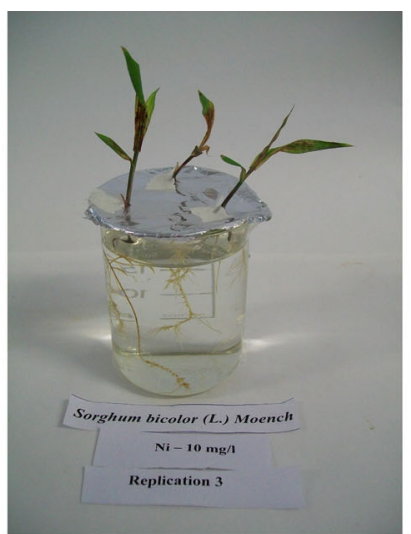

S. bicolor - Ni10

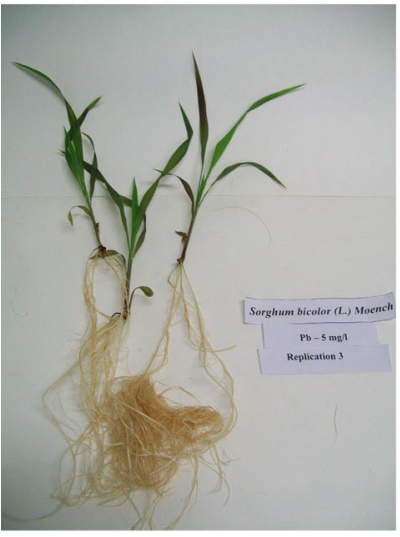

S. bicolor - Pb5

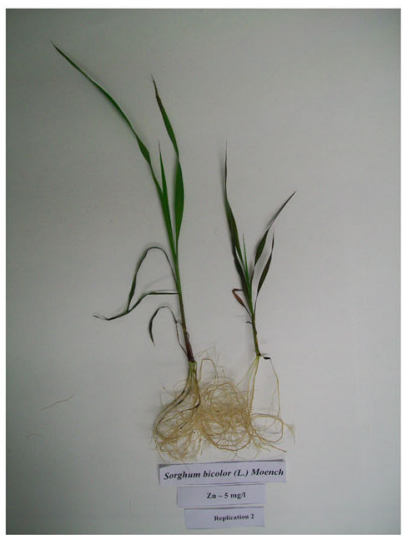

S. bicolor - Zn5

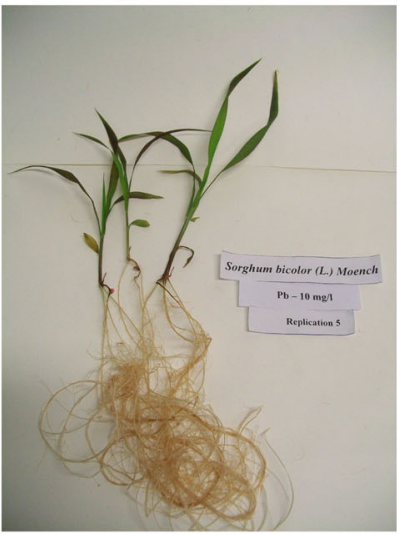

S. bicolor $-\mathrm{Pb} 10$

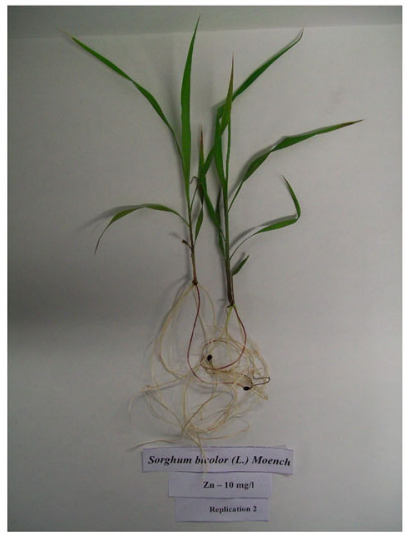

S. bicolor $-\mathrm{Zn} 10$

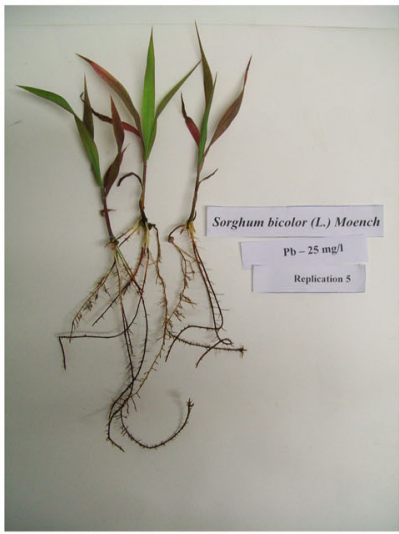

S. bicolor $-\mathrm{Pb} 25$

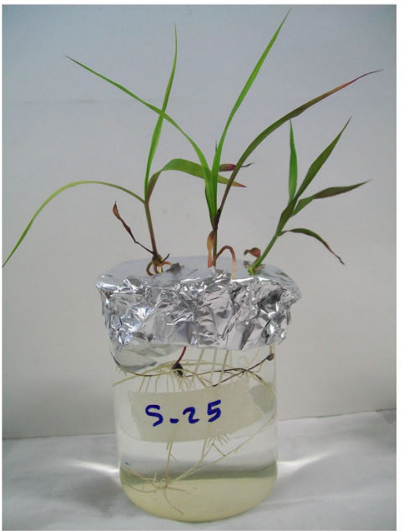

S. bicolor $-\mathrm{Zn} 25$

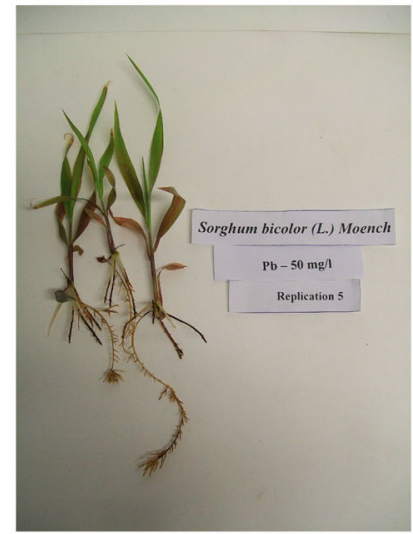

S. bicolor - $\mathrm{Pb} 50$

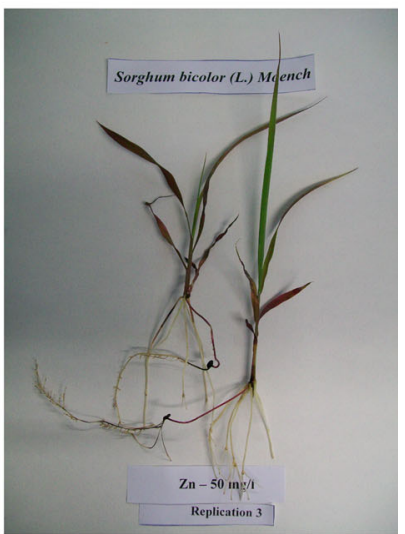

S. bicolor - Zn50

Fig. 1 Growth performance and toxicity symptoms on S. bicolor

tinctorius. These results are in accordance with Kachout et al. (2009) who reported that even if $\mathrm{Ni}$ is an essential element for plants at low concentrations, it is, however, extremely toxic at high concentrations on the annual halophytes Atriplex hortensis and Atriplex rosea. These results were confirmed by Amer et al. (2013) who studied the effect of Ni on Atriplex halimus, Portulaca oleracea and Medicago lupulina. Moreover, several enzyme activities depend on the presence of $\mathrm{Ni}$ ion, which can explain the promoting effects of low $\mathrm{Ni}$ concentrations on plant growth and development (Gerendas and Sattelmacher 1999). In addition, Carlson et al. (1991) found that 


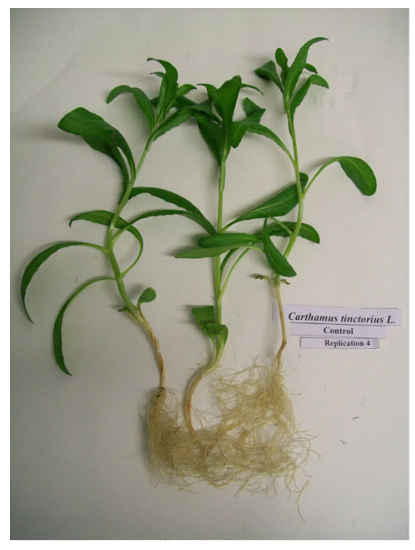

C. tinctorius - CTR

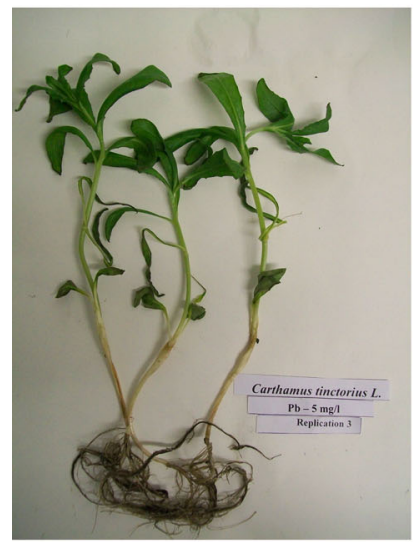

C. tinctorius - $\mathrm{Pb} 5$

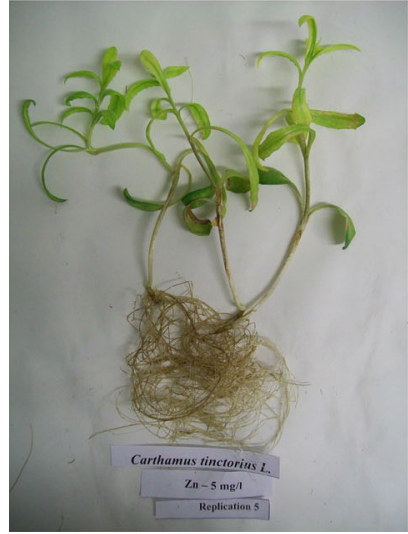

C. tinctorius - Zn5

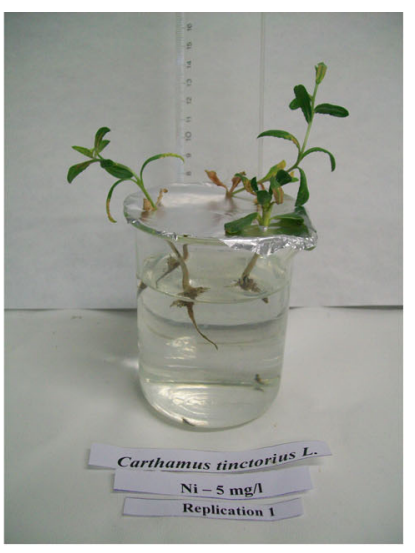

C. tinctorius - Ni5

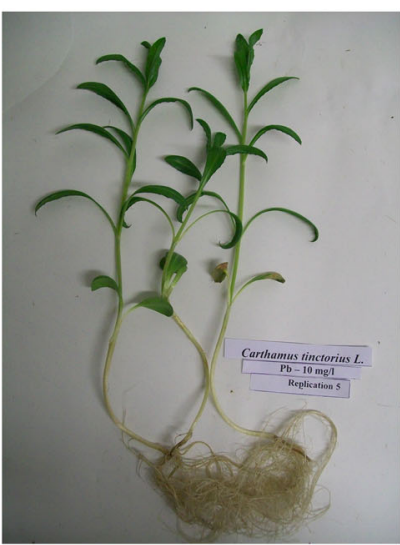

C. tinctorius $-\mathrm{Pb} 10$

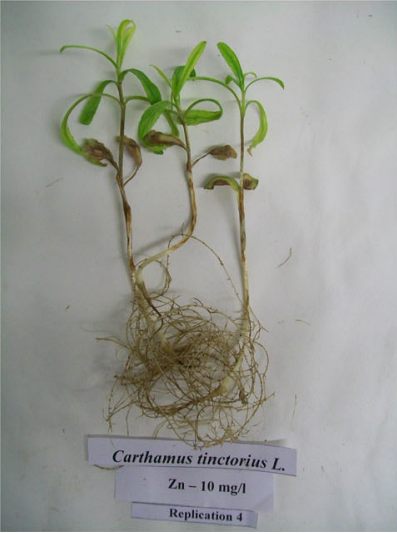

C. tinctorius - Zn10

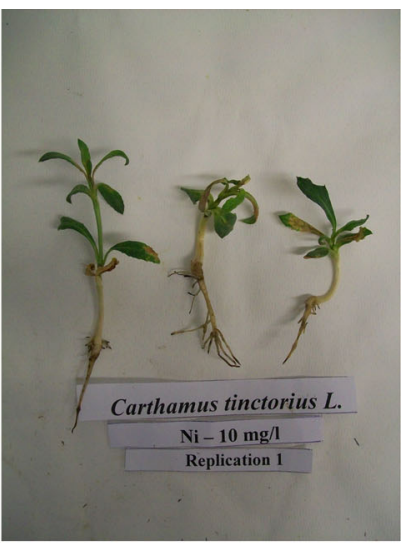

C. tinctorius - Ni10

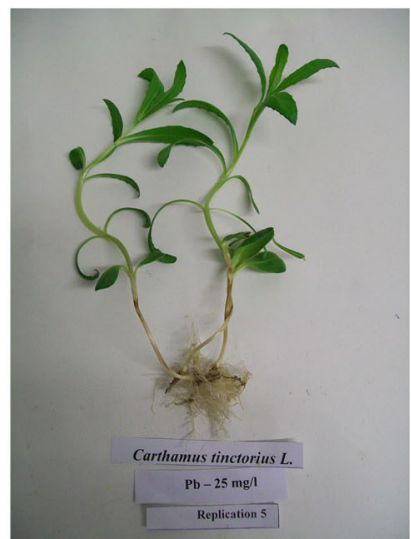

C. tinctorius - $\mathrm{Pb} 25$

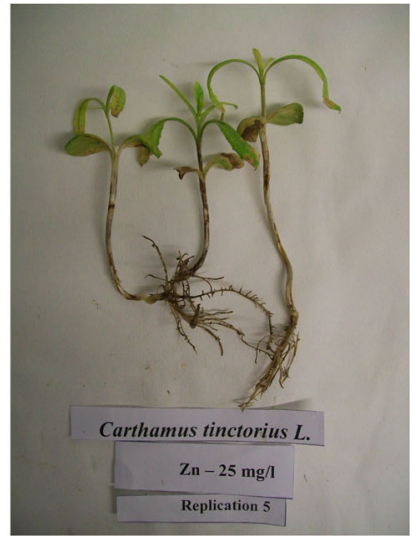

C. tinctorius - Zn25

Fig. 2 Growth performance and toxicity symptoms on C. tinctorius

concentration of $\mathrm{Ni}>1 \mathrm{mg} \mathrm{L}^{-1}$ was enough to cause $50 \%$ reduction in root elongation for several vegetable crops. There is a narrow concentration range between beneficial effects of $\mathrm{Ni}$ as micronutrient and its toxic effects on plant species as contaminated metal.
Lead was less toxic than Ni. S. bicolor plants continued to grow till a concentration of $100 \mathrm{mg} \mathrm{L}^{-1}$ in solution, while $C$. tinctorius was less tolerant and was not able to resist a concentration above $25 \mathrm{mg} \mathrm{L}^{-1}$ in solution. $\mathrm{Pb} 5$ and $\mathrm{Pb} 10$ treatments had no effects on $C$. tinctorius growth. In fact, no 
Table 1 Shoot and root dry weight expressed in $\mathrm{g}$ plant ${ }^{-1}$, shoot and root length expressed in $\mathrm{cm}$, and both expressed as percentage of the control

\begin{tabular}{|c|c|c|c|c|c|c|c|c|c|c|c|c|c|c|c|c|}
\hline \multirow[t]{3}{*}{ Treatments } & \multicolumn{8}{|l|}{ S. bicolor } & \multicolumn{8}{|c|}{ C. tinctorius } \\
\hline & \multicolumn{2}{|l|}{ SDW } & \multicolumn{2}{|l|}{ RDW } & \multicolumn{2}{|l|}{ SL } & \multicolumn{2}{|l|}{ RL } & \multicolumn{2}{|l|}{ SDW } & \multicolumn{2}{|l|}{ RDW } & \multicolumn{2}{|l|}{ SL } & \multicolumn{2}{|l|}{ RL } \\
\hline & g plant $^{-1}$ & $\%$ & g plant ${ }^{-1}$ & $\%$ & $\mathrm{~cm}$ & $\%$ & $\mathrm{~cm}$ & $\%$ & g plant ${ }^{-1}$ & $\%$ & g plant $^{-1}$ & $\%$ & $\mathrm{~cm}$ & $\%$ & $\mathrm{~cm}$ & $\%$ \\
\hline CTR & $0.0849^{\mathrm{b}}$ & 100 & $0.1090^{\mathrm{a}}$ & 100 & $26.1^{\mathrm{b}}$ & 100 & $49.2^{\mathrm{a}}$ & 100 & $0.3698^{\mathrm{a}}$ & 100 & $0.0547^{\mathrm{a}}$ & 100 & $26.6^{\mathrm{a}}$ & 100 & $19.3^{\mathrm{a}}$ & 100 \\
\hline Ni5 & $0.0941^{\mathrm{a}}$ & 111 & $0.0755^{\mathrm{b}}$ & 69 & $31.2^{\mathrm{a}}$ & 120 & $33.3^{\mathrm{b}}$ & 68 & $0.0841^{\mathrm{b}}$ & 23 & $0.0140^{\mathrm{b}}$ & 26 & $9.7^{\mathrm{b}}$ & 36 & $2.9^{\mathrm{b}}$ & 15 \\
\hline Ni10 & $0.0171^{\mathrm{c}}$ & 20 & $0.0123^{\mathrm{c}}$ & 11 & $7.1^{\mathrm{c}}$ & 27 & $8.2^{\mathrm{c}}$ & 17 & $0.0610^{\mathrm{b}}$ & 17 & $0.0099^{\mathrm{b}}$ & 18 & $6.1^{\mathrm{b}}$ & 23 & $1.6^{\mathrm{c}}$ & 8 \\
\hline $\mathrm{Ni} 25$ & ng & ng & ng & ng & ng & ng & ng & ng & & & & & & & & \\
\hline CTR & $0.0849^{\mathrm{a}}$ & 100 & $0.1090^{\mathrm{a}}$ & 100 & $26.1^{\mathrm{a}}$ & 100 & $49.2^{\mathrm{a}}$ & 100 & $0.3698^{\mathrm{a}}$ & 100 & $0.0547^{\mathrm{a}}$ & 100 & $26.6^{\mathrm{a}}$ & 100 & $19.3^{\mathrm{a}}$ & 100 \\
\hline $\mathrm{Pb} 5$ & $0.0627^{\mathrm{b}}$ & 74 & $0.1141^{\mathrm{a}}$ & 105 & $19.5^{\mathrm{b}}$ & 75 & $51.8^{\mathrm{a}}$ & 105 & $0.3108^{\mathrm{b}}$ & 84 & $0.0618^{\mathrm{a}}$ & 113 & $27.5^{\mathrm{a}}$ & 103 & $22.8^{\mathrm{a}}$ & 118 \\
\hline $\mathrm{Pb} 10$ & $0.0454^{\mathrm{c}}$ & 53 & $0.0741^{\mathrm{b}}$ & 68 & $16.4^{\mathrm{b}}$ & 63 & $36.7^{\mathrm{b}}$ & 74 & $0.2224^{\mathrm{c}}$ & 60 & $0.0600^{\mathrm{a}}$ & 110 & $21.3^{\mathrm{b}}$ & 80 & $21.2^{\mathrm{a}}$ & 110 \\
\hline $\mathrm{Pb} 25$ & $0.0386^{\mathrm{c}}$ & 45 & $0.0489^{c}$ & 45 & $10.9^{c}$ & 42 & $13.1^{\mathrm{c}}$ & 27 & $0.0859^{\mathrm{d}}$ & 23 & $0.0129^{\mathrm{b}}$ & 23 & $20.7^{\mathrm{b}}$ & 78 & $5.8^{\mathrm{c}}$ & 30 \\
\hline $\mathrm{Pb} 50$ & $0.0402^{\mathrm{c}}$ & 47 & $0.0384^{\mathrm{d}}$ & 35 & $12.6^{\mathrm{c}}$ & 48 & $14.6^{\mathrm{c}}$ & 30 & ng & ng & ng & ng & & & & \\
\hline $\mathrm{Pb} 100$ & $0.0358^{\mathrm{c}}$ & 42 & $0.0365^{\mathrm{d}}$ & 33 & $10.4^{\mathrm{d}}$ & 10 & $9.6^{\mathrm{d}}$ & 19 & ng & ng & ng & ng & & & & \\
\hline CTR & $0.0849^{\mathrm{a}}$ & 100 & $0.1090^{\mathrm{a}}$ & 100 & $26.1^{\mathrm{a}}$ & 100 & $49.2^{\mathrm{a}}$ & 100 & $0.3698^{\mathrm{a}}$ & 100 & $0.0547^{\mathrm{a}}$ & 100 & $26.6^{\mathrm{a}}$ & 100 & $19.3^{\mathrm{a}}$ & 100 \\
\hline Zn5 & $0.0801^{\mathrm{a}}$ & 94 & $0.0734^{\mathrm{b}}$ & 67 & $25.1^{\mathrm{a}}$ & 96 & $53.4^{\mathrm{a}}$ & 109 & $0.1184^{\mathrm{b}}$ & 32 & $0.0293^{\mathrm{b}}$ & 54 & $17.1^{\mathrm{b}}$ & 64 & $18.4^{\mathrm{a}}$ & 95 \\
\hline Zn10 & $0.0488^{\mathrm{b}}$ & 57 & $0.0403^{c}$ & 37 & $17.6^{\mathrm{b}}$ & 67 & $32.3^{\mathrm{b}}$ & 66 & $0.0572^{\mathrm{c}}$ & 15 & $0.0122^{\mathrm{c}}$ & 22 & $12.4^{\mathrm{c}}$ & 47 & $12.6^{\mathrm{b}}$ & 65 \\
\hline $\mathrm{Zn} 25$ & $0.0301^{\mathrm{c}}$ & 35 & $0.0299^{\mathrm{d}}$ & 27 & $11.2^{\mathrm{cd}}$ & 43 & $17.0^{\mathrm{c}}$ & 35 & $0.0462^{\mathrm{c}}$ & 13 & $0.0083^{c}$ & 15 & $8.6^{\mathrm{c}}$ & 32 & $5.8^{\mathrm{c}}$ & 30 \\
\hline Zn50 & $0.0307^{\mathrm{c}}$ & 36 & $0.0196^{\mathrm{e}}$ & 18 & $12.8^{\mathrm{c}}$ & 49 & $13.6^{\mathrm{d}}$ & 28 & ng & ng & ng & ng & & & & \\
\hline Zn100 & $0.0156^{\mathrm{d}}$ & 18 & $0.0098^{f}$ & 9 & $9.8^{\mathrm{d}}$ & 38 & $7.3^{\mathrm{e}}$ & 15 & ng & ng & ng & ng & & & & \\
\hline
\end{tabular}

Values are mean \pm standard deviation $(n=5)$

Means with different letters within the column of the same species indicate significant difference between values; LSD test $(P<0.05)$

$S D W$ shoot dry weight, $R D W$ root dry weight, $S L$ shoot length, $R L$ root length, $n g$ no growth

significant difference in comparison with control was observed on all growth parameters. Conversely, severe toxicity symptoms were observed in $\mathrm{Pb} 25$ treatment, whereas no growth was observed at Pb50 and Pb100 treatments. S. bicolor behaved differently than $C$. tinctorius. In fact, slight reduction in growth started to be observed at $\mathrm{Pb} 5$. Growth reduction started to be severe at higher $\mathrm{Pb}$ concentration. However, S. bicolor continued to grow even in $\mathrm{Pb} 100$ treatment. $\mathrm{Pb}$ is a toxic metal and is not considered an essential element for plant growth, but it may stimulate the growth of some plants at very low concentration (Dou 1988). However, in our case, no stimulation effect of $\mathrm{Pb}$ at low concentration was observed on our investigated plants. Our findings are in disagreement with many studies showing that small amounts of $\mathrm{Pb}$ in plant tissues may have a stimulation effect on Brassica juncea (L.) (Liu et al. 2000). In addition, our results are in contrast with Amer et al. (2013) who found that $\mathrm{Pb}$ at low concentration has a stimulation effect on $A$. halimus, $P$. oleracea and M. lupulina. Toxicity symptoms and biomass reduction are some of the physiological responses to metals exposure exhibited by plants. In this study, $\mathrm{Pb}$ concentration at $10 \mathrm{mg} \mathrm{L}^{-1}$ exhibited a severe growth reduction and reduced shoot and root biomass. Wierzbicka et al. (2007) confirmed that $\mathrm{Pb}$ affects water potential that causes dehydration in plant tissues, thus influencing plant development and resulting in growth reduction. According to Sharma and Dubey (2005), $\mathrm{Pb}$ affects plant physiology by inhibition of enzymatic activities, alteration of mineral nutrition and membrane permeability.

Zinc toxicity symptoms and growth reduction were observed on S. bicolor at concentration above $10 \mathrm{mg} \mathrm{L}^{-1}$, whereas severe $\mathrm{Zn}$ toxicity symptoms and growth reduction started to be observed on C. tinctorius at low $\mathrm{Zn}$ concentration. In Zn10 treatment, S. bicolor plants had toxicity symptoms, and SDW, RDW, SL and RL were lower than the CTR by 43, 66, 33 and $34 \%$, respectively. However, $S$. bicolor continued to grow even in $\mathrm{Zn} 100$ treatment, while no growth of $C$. tinctorius in $\mathrm{Zn} 50$ and $\mathrm{Zn} 100$ treatments. Zn did not show any promoting effect within our concentrations, which is in contrast with the findings of Grifferty and Barrington (2000), who showed that the increased $\mathrm{Zn}$ concentration from 25 to $50 \mathrm{mg} \mathrm{kg}^{-1}$ had a significant positive effect on the dry biomass yield of wheat plants. In addition, Sridhar et al. (2007) reported that $\mathrm{Zn}$ acts as a growth promoting micronutrient at low concentrations on barley plants. According to Jadia and Fulekar (2008), soil with low concentration of $\mathrm{Pb}, \mathrm{Ni}$ and $\mathrm{Zn}$ from 5 to $20 \mathrm{mg} \mathrm{kg}^{-1}$ was observed to stimulate the root and shoot length and increase biomass of the $M$. sativa plants. In our study, low-to-moderate toxicity was observed for both 
species in treatments with $\mathrm{Zn}$ below $10 \mathrm{mg} \mathrm{L}^{-1}$, while severe toxicity symptoms were observed in treatments with $\mathrm{Zn}$ concentration above $10 \mathrm{mg} \mathrm{L}^{-1}$. $\mathrm{Ni}$ and $\mathrm{Zn}$ in elevated concentration can lead to the formation of reactive oxygen species and improper protein binding, which can alter the protein structure (Yang et al. 2006). Our study points out that $S$. bicolor, the most Ni resistant species among the tested plants, could be used for $\mathrm{Ni}$ phytoremediation in case of low levels of soil contamination.

It is worth noting that $\mathrm{Ni}$ and $\mathrm{Zn}$ were unable to induce a stimulating effect of the studied plant species, despite their important functions for plant growth. Ni and $\mathrm{Zn}$, as redoxactive metals, play a role of cofactors in many metalloenzymes, being $\mathrm{Zn}$ also active as protein stabilizer (Hansch and Mendel 2009). Ni and $\mathrm{Zn}$ are typically present in plant cells at concentrations of $15-22$ and $15-50 \mathrm{mg} \mathrm{kg}^{-1}$, respectively (Hansch and Mendel 2009).

\section{Heavy metal content, uptake and translocation factor}

Total metal concentrations in shoots and roots are shown in Fig. 3. Large amounts of metals were accumulated in shoots and roots of $S$. bicolor and $C$. tinctorius. This amount significantly varied among plant species, metals and treatments. Within our experimental conditions, $\mathrm{Ni}, \mathrm{Pb}$ and $\mathrm{Zn}$ content in shoots and roots increased as the concentrations of these metals in the growing media increased.

Our results showed that $S$. bicolor and $C$. tinctorius do not belong to $\mathrm{Ni}, \mathrm{Pb}$ and $\mathrm{Zn}$ hyperaccumulating plants because metal content was higher in the roots. Similar results were found by Soudek et al. (2014) who studied the accumulation of $\mathrm{Cd}$ and $\mathrm{Zn}$ on Sorgum sp. According to Baker and Brooks (1989) criterion, S. bicolor and C. tinctorius cannot be considered as $\mathrm{Pb}, \mathrm{Ni}$ or $\mathrm{Zn}$ hyperaccumulators as the concentration of $\mathrm{Ni}, \mathrm{Pb}$ and $\mathrm{Zn}$ were $<1000 \mu \mathrm{g} \mathrm{g}^{-1} \mathrm{dw}$ for $\mathrm{Ni}$ and $\mathrm{Pb}$, and $<10,000 \mu \mathrm{g} \mathrm{g}^{-1} \mathrm{dw}$ for $\mathrm{Zn}$ in their leaves. However, the concentrations of metals achieved in plant tissues together with their high biomass production lead to the suggestion that the studied species could be used for phytoremediation applications combined with biomass production for bioenergy purposes.

Zinc was the dominant metal in shoots followed by $\mathrm{Pb}$. The highest $\mathrm{Zn}$ concentration $\left(4395 \mathrm{mg} \mathrm{kg}^{-1} \mathrm{dw}\right.$ ) was observed in $S$ bicolor shoots in the $\mathrm{Zn} 100$ treatment. The highest $\mathrm{Pb}$ concentration $\left(2292 \mathrm{mg} \mathrm{kg}^{-1} \mathrm{dw}\right.$ ) was found in C. tinctorius shoots in the $\mathrm{Pb} 25$ treatment. Lead was the dominant metal in roots followed by $\mathrm{Zn}$. The highest $\mathrm{Pb}$ concentration $\left(36,229 \mathrm{mg} \mathrm{kg}^{-1} \mathrm{dw}\right)$ was found in C. tinctorius roots in the P25 treatment. Similar amounts of $\mathrm{Zn}$ concentration were found in $C$. tinctorius roots in the $\mathrm{Zn} 25$ treatment $\left(9273 \mathrm{mg} \mathrm{kg}^{-1} \mathrm{dw}\right)$ and $S$. bicolor roots in the Zn100 treatment $\left(9230 \mathrm{mg} \mathrm{kg}^{-1} \mathrm{dw}\right)$.
Yoon et al. (2006) studied the accumulation of $\mathrm{Pb}, \mathrm{Cu}$ and $\mathrm{Zn}$ in native plants (17 species) growing on a contaminated Florida site. Total $\mathrm{Pb}$ concentrations in the plants ranged from non-detectable to $1183 \mathrm{mg} \mathrm{kg}^{-1}$, while $\mathrm{Zn}$ content ranged from 17 to $598 \mathrm{mg} \mathrm{kg}^{-1}$. Most of the plant samples, the root $\mathrm{Pb}$ and $\mathrm{Zn}$ concentrations were much greater than those of the shoot $\mathrm{Pb}$ contents, indicating low mobility of $\mathrm{Pb}$ from the roots to the shoots. Similar results were obtained by Pitchtel et al. (2000) who studied the distribution of $\mathrm{Pb}, \mathrm{Cd}$ and $\mathrm{Ba}$ in soils and plants of two contaminated sites. Also, Stoltz and Greger (2002) reported a $\mathrm{Pb}$ range from 3.4 to $920 \mathrm{mg} \mathrm{kg}^{-1}$ and $\mathrm{Zn}$ concentrations range from 68 to $1630 \mathrm{mg} \mathrm{kg}^{-1}$, while $\mathrm{Zn}$ concentration found by Shu et al. (2002) ranged from 66 to $7607 \mathrm{mg} \mathrm{kg}^{-1}$ in plant biomass. In our study, metal concentration in the shoots was in the order $\mathrm{Zn}>\mathrm{Pb}>\mathrm{Ni}$, whereas the metal concentration in the roots was in the order $\mathrm{Pb}>\mathrm{Zn}>\mathrm{Ni}$. Similar results were obtained by Meers et al. (2005) who noted that Helianthus annuus and Z. mays showed more uptake of than Ni. This could be due to the fact that $\mathrm{Pb}$ uptake does not require any energetic expense, and it was deposited in large amounts in the roots (Wierzbicka et al. 2007). Brown and Slingsby (1972) showed that the high tolerance of $\mathrm{Pb}$ in plants results from $\mathrm{Pb}$ accumulation only in the cell wall without penetrating into the protoplast. Root growth decreased progressively with increasing concentration of $\mathrm{Pb}$ in solutions. Meers et al. (2005) reported that shoot selectivity of $H$. annuus was in the order of $\mathrm{Zn}>\mathrm{Cu}>\mathrm{Ni}>\mathrm{Cd}=\mathrm{Pb}$, while in Indian mustard, shoot selectivity was in the order of $\mathrm{Zn}>\mathrm{Cd}>\mathrm{Ni}>\mathrm{Cu}>\mathrm{Pb}$ (Do Nascimento et al. 2006). Jadia and Fulekar (2008) reported that plant growth was adversely affected by heavy metals at higher concentration ( 40 and $50 \mathrm{mg} \mathrm{kg}^{-1}$ ). Furthermore, metals were efficiently taken up mainly by roots; the order of uptake was: $\mathrm{Zn}>\mathrm{Ni}>\mathrm{Pb}$. Bonfranceschi et al. (2009) found that the increases in metal concentration in the hydroponic solution lead to a great accumulation at the root level in M. sativa and S. bicolor.

Several plant species are able to accumulate higher concentrations of $\mathrm{Zn}$ in the shoots (e.g., red beet, field pumpkin, chicory), whereas other plants accumulate zinc in the roots (e.g., barley, white cabbage, maize) (Sekara et al. 2005). Baker (1981) reported that metal uptake and transport of indicator plants were regulated in such a way that the ratio of the concentration of element in the plant to that in the soil is close to 1 . Thus, in our study, S. bicolor and $C$. tinctorius could be considered excluders for $\mathrm{Ni}, \mathrm{Pb}$ and $\mathrm{Zn}$. It has been shown that $\mathrm{Pb}$ is mainly located in roots. Kabata-pendias (2011) reported that plant uptake of $\mathrm{Pb}$ increased with the increasing concentration in the solution and the translocation from root to shoot was greatly limited. According to Wallace and Romney (1977), the accumulation of $\mathrm{Pb}$ occurs mostly in the root tissues of $S$. 
Fig. 3 Total $\mathrm{Ni}, \mathrm{Pb}$ and $\mathrm{Zn}$ contents in shoots (a) and roots (b). Means with different letters within the same species and metal indicate significant difference between values; LSD test $(P<0.05) .{ }^{*} C$ tinctorius: no growth
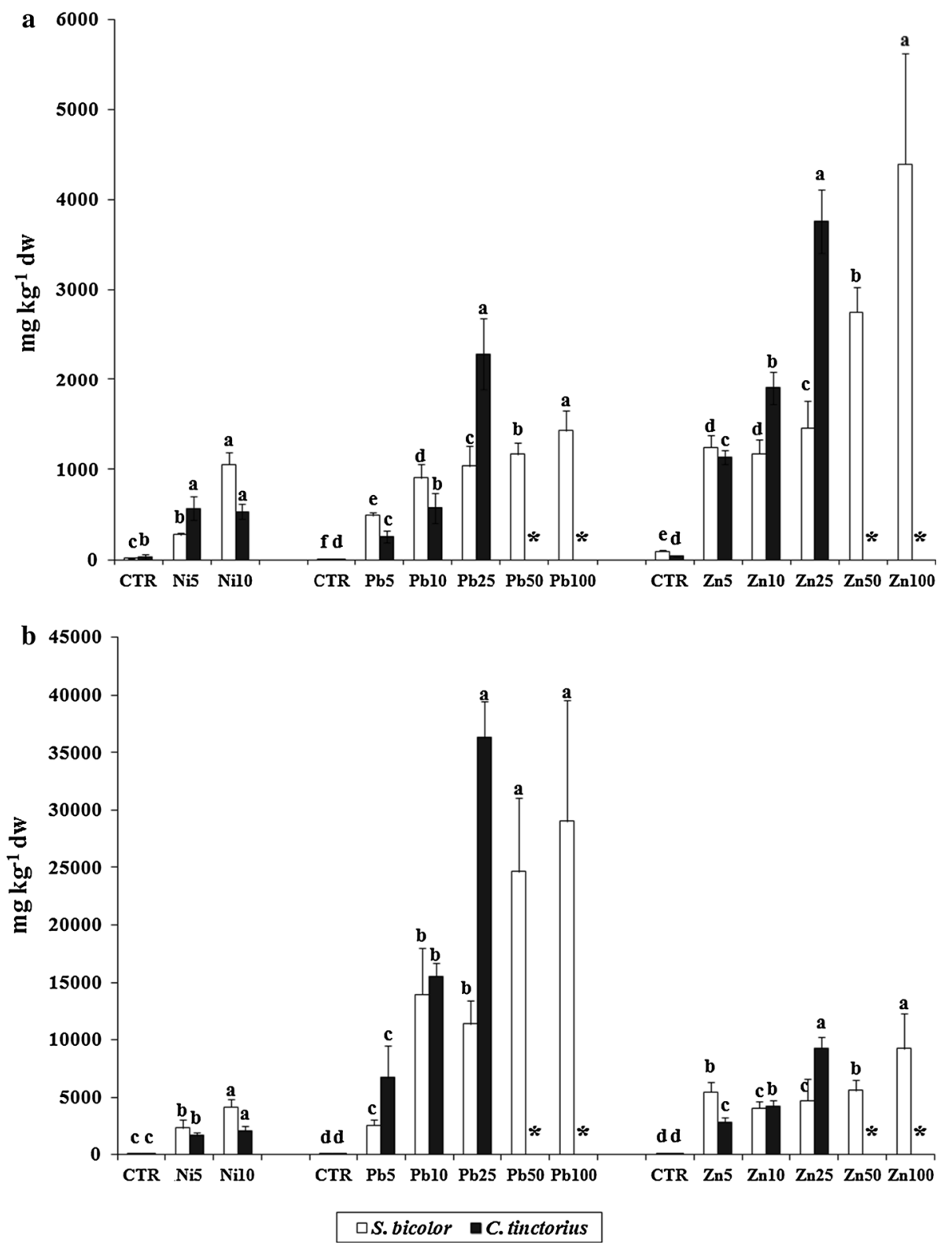

bicolor and $H$. annuus. Root tissues act as barriers to apoplastic and symplastic $\mathrm{Pb}$ transport, and therefore, $\mathrm{Pb}$ transport to shoot gets restricted (John et al. 2009). Metal tolerance is often associated with enhanced metal retention in roots, but that does not necessarily mean that increased root retention itself could be the cause of tolerance (Harmens et al. 1993). However, metal tolerance and root to shoot metal transport are often negatively correlated. High content of $\mathrm{Pb}$ was found in the roots for all species under our conditions. Similar results were obtained by Amer et al. (2013) who conducted similar experiment on A. halimus, $M$. sativa and $P$. oleracea, and they found similar concentrations that were accumulated in plant roots. This high $\mathrm{Pb}$ concentration could be due to the low biomass of the roots, which results in high concentration of the metal in the roots, or could be due also to the precipitation of the metal on the root surface. However, before analysis, roots were exposed for $2 \mathrm{~h}$ to a solution of $0.05 \mathrm{M} \mathrm{CaCl}_{2}$ acidified at $\mathrm{pH} 2-3$ with $\mathrm{HCl}$ in order to remove adsorbed metals on root surface. Roots were subsequently washed with distilled water. However, similar concentration of $\mathrm{Pb}$ was reported by Sahi et al. (2002) who found that Sesbania drummondii, a leguminous shrub, can tolerate $\mathrm{Pb}$ levels up to $1500 \mathrm{mg} \mathrm{L}^{-1}$ and accumulate up to $40 \mathrm{~g} \mathrm{~kg}^{-1}$ shoot dw. In addition, Kumar et al. (1995) found that B. juncea can accumulate $\mathrm{Pb}$ up to $34.5 \mathrm{~g} \mathrm{~kg}^{-1}$ shoot dry weight. Variation of the TF from roots to other organs might be due to the interaction between different metals occurring at the root surface and also within the plant (Ashraf et al. 2011; Sharma et al. 2007). 
Table 2 Total metal uptake in shoots and roots

\begin{tabular}{|c|c|c|c|c|}
\hline \multirow[t]{2}{*}{ Treatments } & \multicolumn{2}{|l|}{ S. bicolor } & \multicolumn{2}{|l|}{ C. tinctorius } \\
\hline & $\begin{array}{l}\text { Shoot uptake } \\
\mu \mathrm{g} / \text { plant }\end{array}$ & Root uptake & Shoot uptake & Root uptake \\
\hline Ni5 & 26 & 312 & 48 & 23 \\
\hline Ni10 & 18 & 29 & 33 & 21 \\
\hline $\mathrm{Ni25}$ & ng* & ng & ng & ng \\
\hline $\mathrm{Pb} 5$ & 31 & 294 & 78 & 415 \\
\hline $\mathrm{Pb} 10$ & 41 & 1033 & 129 & 932 \\
\hline $\mathrm{Pb} 25$ & 40 & 557 & 197 & 467 \\
\hline $\mathrm{Pb} 50$ & 47 & 945 & ng & ng \\
\hline $\mathrm{Pb} 100$ & 51 & 1060 & ng & ng \\
\hline Zn5 & 100 & 399 & 135 & 83 \\
\hline $\mathrm{Zn} 10$ & 57 & 164 & 110 & 51 \\
\hline $\mathrm{Zn} 25$ & 44 & 141 & 174 & 77 \\
\hline Zn50 & 85 & 109 & ng & ng \\
\hline Zn100 & 68 & 90 & ng & ng \\
\hline
\end{tabular}

CTR: control; Ni5, Ni10 and Ni25: nickel concentration of 1, 2 and $5 \mathrm{mg} \mathrm{L}^{-1}$, respectively; Zn5, Zn10, $\mathrm{Zn} 25, \mathrm{Zn} 50$ and $\mathrm{Zn} 100$ : zinc concentration of 5, 10, 25, 50 and $100 \mathrm{mg} \mathrm{L}^{-1}$, respectively; $\mathrm{Pb} 5, \mathrm{~Pb} 10, \mathrm{~Pb} 25$, $\mathrm{Pb} 50$ and $\mathrm{Pb} 100$ : lead concentration of 5, 10, 25, 50 and $100 \mathrm{mg} \mathrm{L}^{-1}$, respectively

$* \mathrm{ng}=$ no growth

S. bicolor and $C$. tinctorius potential for phytoremediation can be evaluated by both TU and TF. Total metal uptake (TU) in shoots and roots is shown in Table 2 . Ni TU was the lowest in all tested plants in all treatments, followed by $\mathrm{Zn}$; the highest uptake was found for $\mathrm{Pb}$. $C$. tinctorius showed higher TU than $S$. bicolor for all tested metals. Root uptake was higher than shoot uptake for all tested plants in all treatments. Metal uptake was higher in roots than in shoots. These results agree with Amer et al. (2013) who found that roots are the main accumulation site for $\mathrm{Ni}, \mathrm{Pb}$ and $\mathrm{Zn}$, while only a limited amount was translocated to shoots. In contrast, $\mathrm{Zn}$ was very mobile and a significant amount was translocated to shoots. In fact, Al Chami et al. (2013) and Terzano et al. (2008) found that $\mathrm{Zn}$ was translocated to shoots with a TF between 0.7 and 1.1. High shoot biomass produced can compensate for the low metal concentration and translocation. An important amount of $\mathrm{Zn}$ was translocated to shoots in comparison with $\mathrm{Ni}$ and $\mathrm{Pb}$. These results are in agreement with Adesodun et al. (2010) who found that the translocation of $\mathrm{Zn}$ from root to shoot for Tithonia diversifolia and $H$. annuus was higher than $\mathrm{Pb}$. Baker and Brooks (1989) also discussed restriction of metal uptake by plants from contaminated soils and the presence of exclusion mechanisms in such plant species. Since $\mathrm{Zn}$ and $\mathrm{Ni}$ are essential nutrients for plant systems, higher translocation from roots to shoots in comparison with $\mathrm{Pb}$ is understandable. Considering that roots are the main accumulation site of $\mathrm{Ni}, \mathrm{Pb}$ and $\mathrm{Zn}$ for all studied species in all used metal concentrations, these plant species are potential candidates to be used in phytoremediation process, but in phytostabilization and not phytoextraction. In highly polluted areas, where the removal of metals by phytoextraction using hyperaccumulating plants is not efficient due to the slowness of the process (Ernst 1996), the most suitable method is phytostabilization (Arthur et al. 2005). TF is shown in Table 3. TF was very low for all tested plants in all treatments $(<0.5)$, being the roots the tissues in

Table 3 Translocation factor

\begin{tabular}{llllll}
\hline Species & Treatments & TF & Species & Treatments & TF \\
\hline S. bicolor & Ni5 & 0.07 & C. tinctorius & Ni5 & 0.34 \\
& Ni10 & 0.45 & & Ni10 & 0.26 \\
& Ni25 & ng* & Ni25 & ng \\
& Pb5 & 0.19 & $\mathrm{Pb5}$ & 0.04 \\
& Pb10 & 0.07 & $\mathrm{~Pb} 10$ & 0.04 \\
& Pb25 & 0.09 & $\mathrm{~Pb} 25$ & 0.06 \\
& $\mathrm{Pb50}$ & 0.05 & $\mathrm{Pb50}$ & $\mathrm{ng}$ \\
& $\mathrm{Pb} 100$ & 0.05 & $\mathrm{~Pb} 100$ & $\mathrm{ng}$ \\
& $\mathrm{Zn5}$ & 0.23 & $\mathrm{Zn5}$ & 0.40 \\
$\mathrm{Zn10}$ & 0.29 & $\mathrm{Zn10}$ & 0.45 \\
$\mathrm{Zn25}$ & 0.31 & $\mathrm{Zn25}$ & 0.41 \\
$\mathrm{Zn50}$ & 0.49 & $\mathrm{Zn50}$ & $\mathrm{ng}$ \\
$\mathrm{Zn100}$ & 0.48 & $\mathrm{Zn100}$ & $\mathrm{ng}$ \\
\hline
\end{tabular}

CTR: control; Ni5, Ni10 and Ni25: nickel concentration of 1, 2 and $5 \mathrm{mg} \mathrm{L}^{-1}$, respectively; $\mathrm{Zn} 5, \mathrm{Zn} 10, \mathrm{Zn} 25, \mathrm{Zn} 50$ and $\mathrm{Zn} 100$ : zinc concentration of 5, 10, 25, 50 and $100 \mathrm{mg} \mathrm{L}^{-1}$, respectively; $\mathrm{Pb}$, $\mathrm{Pb} 10, \mathrm{~Pb} 25, \mathrm{~Pb} 50$ and $\mathrm{Pb} 100$ : lead concentration of 5, 10, 25, 50 and $100 \mathrm{mg} \mathrm{L}^{-1}$, respectively

$*$ ng $=$ no growth 
which heavy metals mostly accumulated. The highest TF value was found for $\mathrm{Zn}$, followed by $\mathrm{Ni}$, and both were much greater than $\mathrm{Pb}$. TF values for $S$. bicolor were higher than TF values for $C$. tinctorius. Based on the average TFs of all plant samples, Yoon et al. (2006) found that the plants were most efficient in translocating $\mathrm{Cu}(\mathrm{TF}=1.2)$ followed by $\mathrm{Zn}(\mathrm{TF}=0.98)$ and $\mathrm{Pb}$ $(\mathrm{TF}=0.58)$. Goni et al. (2014) studied the uptake and translocation of metals in different parts of rice plants irrigated with metals contaminated water and found that the TF for all metals was below 1 , which indicates that most of the metals were confined in the roots after rice plant uptake. However, the highest TF was observed for $\mathrm{Zn}$ in edible parts. In our case, $\mathrm{TF}$ for $\mathrm{Zn}$ and $\mathrm{Ni}$ ranged between 0.2 and 0.5 , while $\mathrm{TF}$ for $\mathrm{Pb}$ was below 0.1 . The differences in root and shoot uptake in our study can possibly be explained by the fact that one of the normal functions of roots is to selectively acquire ions from the soil solution, whereas shoot tissue does not normally play this role (Salt et al. 1997). Many metal-tolerant species have restricted translocation of metals to the shoot (Baker and Walker 1990). The reason for restricted shoot metal uptake could be the presence of exclusion mechanisms, maybe for the protection of photosynthesis from toxic levels of heavy metals (Baker 1981; Stoltz and Greger 2002). A higher metal uptake in roots comparing to shoots was reported in grasses, semi-resistant, sensitive and resistant plants including sorghum (Pinto et al. 2004). In this experiment, shoot selectivity was in the order of $\mathrm{Zn}>\mathrm{Pb}>\mathrm{Ni}$. Heavy metals are transported from root to shoot in terrestrial plants to different extents. Different metals are differently mobile, and within a plant, $\mathrm{Zn}$ is more mobile than $\mathrm{Pb}$ (Greger 2004). Zn may be translocated extensively as it is essential to the plant metalloenzymes (Delhaize et al. 1985; Van Assch and Clijsters 1990) and photosynthesis (Hsu and Lee 1988). However, many factors including anatomical, biochemical and physical factors might also contribute to metal uptake, accumulation and distribution in the different plant parts (Salt et al. 1995; Singh et al. 2011).

\section{Conclusion}

Results showed that both plant biomass and metal accumulation varied with the metals considered, their concentrations and the plant species. Metals induced a number of physiological changes, such as growth reduction, chlorosis.

$\mathrm{Ni}$ seems to be more toxic than $\mathrm{Zn}$ and $\mathrm{Pb}$, though physiological changes were more pronounced for $\mathrm{Ni}$ in the studied species. High toxicity symptoms were observed in all studied species at $\mathrm{Pb}$ and $\mathrm{Zn}$ concentrations above $25 \mathrm{mg} \mathrm{L}^{-1}$. Heavy metal content in root was much higher than shoot in all treatments. Heavy metal toxicity ranked as follows: $\mathrm{Ni}>\mathrm{Zn}>\mathrm{Pb}$.

Based on metal concentration in shoots and root and on $\mathrm{TF}$, none of the plant species was identified as hyperaccumulator. Due to the high shoot biomass production and high concentration of metal in S. bicolor and C. tinctorius roots, these plants could be successfully used in phytostabilization and biomass production in marginal soils with moderately heavy metal contamination. Growing plants on contaminated soil will eventually improve the chemical, physical and biological properties of the contaminated soils. In this context, it is essential to point out that the final purpose of any soil remediation process must not be only to remove the contaminants from the polluted soil or to reduce their toxicities, but to restore and ameliorate its overall ecosystems.

In conclusion, our results from hydroponic experiment cannot be directly extrapolated to the phytostabilization performance in the field. However, the results of hydroponic tests about heavy metals tolerance can confirm that tested plant species were found to be tolerant to heavy metals, performed well in hydroponic experiment and could perform better under field conditions. Further field experiments are necessary to confirm our hydroponic experiment results and to quantify precisely, the growth inhibition, biomass production, plant uptake and translocation rates on a long-term basis and in real metalpolluted field conditions.

Acknowledgments The authors would like to acknowledge Prof. Stefano Dumontet, coordinator of the International Ph.D. Programme: Environment, Resources, and Sustainable Development at the University of Napoli "Parthenope", Dipartimento di Scienze per l'Ambiente, for supporting this research work.

\section{References}

Adesodun JK, Atayese MO, Agbaje TA, Osadiaye BA, Mafe OF, Soretire AA (2010) Phytoremediation potentials of sunflowers (Tithonia diversifolia and Helianthus annuus) for metals in soils contaminated with zinc and lead nitrates. Water Air Soil Pollut 207(1-4):195-201

Adriano DC (2001) Trace elements in terrestrial environments: biogeochemistry, bioavailability and risks of metals, 2nd edn. Springer, New York

Al Chami Z, Cavoski I, Mondelli D, Miano T (2013) Effect of compost and manure amendments on zinc speciation, plant content, and translocation in an artificially contaminated soil. Environ Sci Pollut Res 20(7):4766-4776

Al Chami Z, Amer N, Smets K, Yperman J, Carleer R, Dumontet S, Vangronsveld J (2014) Evaluation of flash and slow pyrolysis 
applied on heavy metal contaminated Sorghum bicolor shoots resulting from phytoremediation. Biomass Bioenergy 63:268-279

Amer N, Al Chami Z, Al Bitar L, Mondelli D, Dumontet S (2013) Evaluation of Atriplex halimus, Medicago lupulina and Portulaca oleracea for phytoremediation of $\mathrm{Ni}, \mathrm{Pb}$, and $\mathrm{Zn}$. Int $\mathrm{J}$ Phytoremediation 15(5):498-512

Arthur EL, Rice PJ, Anderson TA, Baladi SM, Henderson KLD, Coats JR (2005) Phytoremediation-an overview. Crit Rev Plant Sci 24:109-122

Ashraf MA, Maah MJ, Yusoff I (2011) Heavy metals accumulation in plants growing in ex tin mining catchment. Int $\mathrm{J}$ Environ Sci Technol 8(2):401-416

Baker AJM (1981) Accumulators and excluders-strategies in the response of plants to heavy metals. J Plant Nutr 3(1-4):643-654

Baker AJM, Brooks RR (1989) Terrestrial higher plants which hyperaccumulate metallic elements. A review of their distribution, ecology and phytochemistry. Biorecovery 1(2):81-126

Baker AJM, Walker PL (1990) Ecophysiology of metal uptake by tolerant plants. In: Shaw AJ (ed) Heavy metal tolerance in plants: evolutionary aspects. CRC Press, Boca Raton, pp 155-177

Barman SC, Sahu RK, Bhargava SK, Chatterjee C (2000) Distribution of heavy metals in wheat, mustard and weed grains irrigated with industrial effluents. Bull Environ Contam Toxicol 64(4):489-496

Begonia GB, Davis CD, Begonia MFT, Gray CN (1998) Growth responses of Indian mustard (Brassica juncea L. Czern) and its phytoextraction of lead from a contaminated soil. Bull Environ Contam Toxicol 61(1):38-43

Bonfranceschi BA, Flocco CG, Donati ER (2009) Study of the heavy metal phytoextraction capacity of two forage species growing in hydroponic environment. J Hazard Mater 165(1-3):366-371

Brown DH, Slingsby DR (1972) The cellular location of lead and potassium in the lichen Cladonia rangiformis (L). New Phytol 71(2):297-305

Carlson CL, Adriano DC, Sajwan KS, Abels SL, Thoma DP, Driver JT (1991) Effects of selected trace metals on germinating seeds of six plant species. Water Air Soil Pollut 59(3-4):231-240

Clemens S, Palmgren MG, Krämer U (2002) A long way ahead: understanding and engineering plant metal accumulation. Trends Plant Sci 7(7):309-315

Council Directive 86/278/EEC (1986) Council directive on the protection of the environment, and in particular of the soil when sewage sludge is used in agriculture. Off $\mathbf{J}$ Eur Communities L181:6-12

Dajue L, Mündel H (1996) Safflower. Carthamus tinctorius L. Promoting the conservation and use of underutilized and neglected crops. 7. Institute of Plant Genetics and Crop Plant Research, Gatersleben/International Plant Genetic Resources Institute, Rome

Delhaize E, Loneragan JF, Webb J (1985) Development of three copper metalloenzymes in clover leaves. Plant Physiol 78(1):4-7

Do Nascimento CWA, Amarasiriwardena D, Baoshan X (2006) Comparison of natural organic acids and synthetic chelates at enhancing phytoextraction of metals from a multi metal contaminated soil. Environ Pollut 140(1):114-123

Dorado MP, Ballesteros E, Lopez FJ, Mittelbach M (2004) Optimization of alkali-catalyzed transesterification of Brassica carinata oil for biodiesel production. Energy Fuels 18(1):77-83

Dou ZX (1988) Lead pollution in soil and its effect on plants. AgroEnviron Prot 7(3):38-39

Ebbs SD, Lasat MM, Brady DJ, Cornish J, Gordon R, Kochian LV (1997) Phytoextraction of cadmium and zinc from a contaminated soil. J Environ Qual 26(5):1424-1430
Elloumi N, Ben F, Rhouma A, Ben B, Mezghani I, Boukhris M (2007) Cadmium induced growth inhibition and alteration of biochemical parameters in almond seedlings grown in solution culture. Acta Physiol Plant 29(1):57-62

EPA (1999) Phytoremediation Resource Guide. US Environmental Protection Agency. EPA 542-B-99-003

EPA (2000) Introduction to phytoremediation. US Environmental Protection Agency. EPA 600-R-99-107

Ernst WHO (1996) Bioavailability of heavy metals and decontamination of soils by plants. Appl Geochem 11(1-2):163-167

European Commission (2008) EU action against climate change. Leading global action to 2020. http://ec.europa.eu/clima/sites/ campaign/pdf/post 2012 en.pdf. Accessed 19 March 2014

Fritioff A, Greger M (2003) Aquatic and terrestrial plant with potential to remove heavy metals from water. Int J Phytoremediation 5(3):211-224

Gerendas J, Sattelmacher B (1999) Influence of Ni supply on growth and nitrogen metabolism of Brassica napus L. Grown with $\mathrm{NH}_{4} \mathrm{NO}_{3}$ or urea as $\mathrm{N}$ source. Ann Bot 83(1):65-71

Goni MA, Ahmed JU, Halim MA, Mottalib MA, Chowdhury DA (2014) Uptake and trans location of metals in different parts of crop plants irrigated with contaminated water from DEZP area of Bangladesh. Bull Environ Contam Toxicol 92(6):726-732

Greger M (2004) Metal availability, uptake, transport and accumulation in plants. In: Prasad MNV (ed) Heavy metal stress in plants from biomolecules to ecosystems, 2nd edn. SpringerVerlag, Berlin, pp 1-27

Grifferty A, Barrington S (2000) Zinc uptake by young wheat plants under two transpiration regimes. J Environ Qual 29(2):443-446

Gupta VK, Ali I (2000) Utilisation of bagasse fly ash (a sugar industry waste) for the removal of copper and zinc from wastewater. Sep Purif Technol 18(2):131-140

Gupta VK, Ali I (2004) Removal of lead and chromium from wastewater using bagasse fly ash - a sugar industry waste. J Colloid Interface Sci 271(2):321-328

Gupta VK, Jain CK, Ali I, Sharma M, Saini VK (2003) Removal of cadmium and nickel from wastewater using bagasse fly ash-a sugar industry waste. Water Res 37(16):4038-4044

Gupta S, Nayek S, Saha RN, Satpati S (2008) Assessment of heavy metal accumulation in macrophyte, agricultural soil and crop plants adjacent to discharge zone of sponge iron factory. Environ Geol 55(4):731-739

Hamby DM (1996) Site remediation techniques supporting environmental restoration activities-a review. Sci Total Environ 191(3):203-224

Hansch R, Mendel R (2009) Physiological functions of mineral micronutrients $(\mathrm{Cu}, \mathrm{Zn}, \mathrm{Mn}, \mathrm{Fe}, \mathrm{Ni}, \mathrm{Mo}, \mathrm{B}, \mathrm{Cl})$. Curr Opin Plant Biol 12(3):259-266

Harmens H, Hartog PRD, Bookum WMT, Verkleij JAC (1993) Increased zinc tolerance in Silene vulgaris (Moench) Garkle is not due to increased production of phytochelatins. Plant Physiol 103:1305-1309

Henry JR (2000) An overview of the phytoremediation of lead and mercury. National network of environmental management studies. National network of environmental management studies (NNEMS) fellow. U.S. Environmental Protection Agency, Office of Solid Waste and Emergency Response, Technology Innovation Office, Washington

Hmid A, Al Chami Z, Sillen W, De Vocht A, Vangronsveld J (2014) Olive mill waste biochar: a promising soil amendment for metal immobilization in contaminated soils. Environ Sci Pollut Res. doi:10.1007/s11356-014-3467-6 
Hsu BD, Lee JY (1988) Toxic effects of copper on photosystem II of spinach chloroplasts. Plant Physiol 87(1):116-119

Jadia CD, Fulekar MH (2008) Phytotoxicity and Remediation of heavy metals by Alfalfa (Medicago sativa) in soil-vermicompost media. Adv Nat Appl Sci 2(3):141-151

John R, Ahmad P, Gadgil K, Sharma S (2009) Heavy metal toxicity: effect on plant growth, biochemical parameters and metal accumulation by Brassica juncea L. Int J Plant Prod 3(3):65-75

Kabata-pendias A (2011) Trace elements in soils and plants, 4th edn. CRC Press, Boca Raton

Kachout SS, Leclerc JC, Ben Mansoura A, Rejeb MN, Ouerghi Z (2009) Effects of heavy metals on growth and bioaccumulation of the annual halophytes A. hortensis and A. rosea. J Appl Sci Res 5(7):746-756

Kumar PBAN, Dushenkov V, Motto H, Raskin I (1995) Phytoextraction - the use of plant to remove heavy metals from soils. Environ Sci Technol 29(55):1232-1238

Liu D, Jiand W, Liu C, Xin C, Hou W (2000) Uptake and accumulation of lead by roots, hypocotyls and shoots of Indian mustard [Brassica juncea (L.)]. Bioresour Technol 71(3):273-277

Luo C, Shen Z, Li X (2005) Enhanced phytoextraction of Cu, Pb, Zn and Cd with EDTA and EDDS. Chemosphere 59(1):1-11

McGrath SP, Zhao FG (2003) Phytoextraction of metals and metalloids from contaminated soils. Curr Opin Biotechnol 14(3):277-282

Meers E, Ruttens A, Hopgood M, Lesage E, Tack FMG (2005) Potential of Brassica rapa, Cannabis sativa, Helianthus annuus and Zea mays for phytoextraction of heavy metals from calcareous dredged sediment derived soils. Chemosphere 61(4):561-572

Millner PD, Kitt DG (1992) The Beltsville method of soilless production of vesicular-arbuscular mycorrhizal fungi. Mycorrhiza 2(1):9-15

Ping Z, Wensheng S, Zhian L, Bin L, Jintian L, Jingsong S (2009) Removal of metals by sorghum plants from contaminated land. J Environ Sci 21:1432-1437

Pinto AP, Mota AM, De Varennes A, Pinto FC (2004) Influence of organic matter on the uptake of cadmium, zinc, copper and iron by sorghum plants. Sci Total Environ 326(1-3):39-247

Pitchtel J, Kuroiwa K, Sawyerr HT (2000) Distribution of Pb, Cd, and $\mathrm{Ba}$ in soils and plants of two contaminated sites. Environ Pollut 110(1):171-178

Renewable Energy World (2000) Bioethanol-industrial world perspective. www.jxj.com/magsandj/rew/200_03/bioethanol.html

Sahi SV, Bryant NL, Sharma NC, Singh SR (2002) Characterization of a lead hyperaccumulator shrub, Sesbania drummondii. Environ Sci Technol 36(21):4676-4680

Salt DE, Blaylock M, Kumar NPBA, Dushenkov V, Ensley BD, Chet I, Raskin I (1995) Phytoremediation: a novel strategy for removal of toxic metals from the environment using plants. Biotechnology 13(5):468-474

Salt DE, Pickering IJ, Prince RC, Gleba D, Dushenkov S, Smith RD, Raskin I (1997) Metal accumulation by aquacultured seedlings of Indian mustard. Environ Sci Technol 31(6):1636-1644

Sekara A, Poniedzialeek M, Ciura J, Jedrszczyk E (2005) Cadmium and lead accumulation and distribution in the organs of nine crops: implications for phytoremediation. Pol J Environ Stud 14(4):509-516

Sharma P, Dubey RS (2005) Lead toxicity in plants. Braz J Plant Physiol 17(1):35-52

Sharma RK, Agrawal M, Marshall F (2007) Heavy metal contamination of soil and vegetables in suburban areas of Varanasi, India. Ecotoxicol Environ Saf 66:258-266

Shi G, Liu C, Cai Q, Liu Q, Hou C (2010) Cadmium accumulation and tolerance of two safflower cultivars in relation to photosynthesis and antioxidative enzymes. Bull Environ Contam Toxicol 85(3):256-263

Shoemaker CE, Bransby DI (2010) The role of sorghum as a bioenergy feedstock. In: Braun R, Karlen D, Johnson D (eds) Sustainable alternative fuel feedstock opportunities, challenges and roadmaps for six U.S. regions. Proceedings of the Sustainable Feedstocks for Advance Biofuels Workshop. 28-30 September 2010, Atalanta, GA. Soil and Water Conservation Society, IA, USA, pp 149-159

Sridhar BBM, Han FX, Diehl SV, Monts DL, Su Y (2007) Effect of $\mathrm{Zn}$ and $\mathrm{Cd}$ accumulation on structural and physiological characteristics of barley plants. Braz J Plant Physiol 19(1):15-22

Shu WS, Ye ZH, Lan CY, Zhang ZQ, Wong MH (2002) Lead, zinc and copper accumulation and tolerance in populations of Paspalum distichum and Cynodon dactylon. Environ Pollut 120(2):445-453

Singh J, Suraj KU, Rajaneesh KP, Gupta V (2011) Accumulation of heavy metals in soil and paddy crop (Oryza sativa) irrigated with water of Ramgarh Lake, Gorakhpur, UP, India. Toxicol Environ Chem 93(3):462-473

Soudek P, Petrova S, Vankova R, Song J, Vanek T (2014) Accumulation of heavy metals using Sorghum sp. Chemosphere 104:15-24

Stolt JP, Sneller FEC, Brynelsson T, Lundborg T, Schat H (2003) Phytochelatin and cadmium accumulation in wheat. Environ Exp Bot 49(1):21-28

Stoltz E, Greger M (2002) Accumulation properties of $\mathrm{As}, \mathrm{Cd}, \mathrm{Cu}, \mathrm{Pb}$ and $\mathrm{Zn}$ by four wetland plant species growing on submerged mine tailings. Environ Exp Bot 47(3):271-280

Terzano R, Al Chami Z, Vekemans B, Janssens K, Miano T, Ruggiero $\mathrm{P}$ (2008) Zinc distribution and speciation within rocket plants (Eruca vesicaria L. Cavalieri) grown on a polluted soil amended with compost as determined by XRF microtomography and micro-XANES. J Agric Food Chem 56(9):3222-3231

Unger PW (2001) Alternative and opportunity dry land crops and related soil conditions in the Southern Great Plains. Agron J 93(11):216-226

Utmazian MNDS, Wieshammer G, Vega R, Wenzel WW (2007) Hydroponic screening for metal resistance and accumulation of cadmium and zinc in twenty clones of willows and poplars. Environ Pollut 148(1):155-165

Van Assch F, Clijsters H (1990) Effects of metals on enzyme activity in plants. Plant, Cell Environ 13(3):195-206

Vangronsveld J, Herzig R, Weyens N, Boulet J, Adriaensen K, Ruttens A, Thewys T, Vassilev A, Meers E, Nehnevajova E, van der Lelie D, Mench M (2009) Phytoremediation of contaminated soils and groundwater: lessons from the field. Environ Sci Pollut Res Int 16(7):765-794

Wallace A, Romney EM (1977) Roots of higher plants as a barrier to translocation of some metals to shoots of plants. In: Drucker $\mathrm{H}$, Wildung RE (eds) Biological implications of metals in the environment. Proceedings of the Fifteenth Annual Hanford Life Science Symposium. Richland, WA. Tech Info Center, ERDA, Washington, DC, pp 370-379

Watson C, Pulford ID, Riddell-Black D (2003) Screening of willow species for resistance to heavy metals: comparison of performance in a hydroponics system and field trials. Int $\mathrm{J}$ Phytoremediation 5(4):351-365

Wenger K, Gupta SK, Furrer G, Schulin R (2002) Zinc extraction potential of two common crop plants, Nicotiana tabacum and Zea mays. Plant Soil 242(2):217-225

Wierzbicka MH, Przedpełska E, Ruzik R, Ouerdane L, Połeć-Pawlak K, Jarosz M, Szpunar J, Szakiel A (2007) Comparison of the toxicity and distribution of cadmium and $\mathrm{Pb}$ in plant cells. Protoplasma 231(1-2):99-111 
Yang M, Cobine PA, Molik S, Naranuntarat A, Lill R, Winge DR, Culotta VC (2006) The effects of mitochondrial iron homeostasis on cofactor specificity of superoxide dismutase 2. EMBO J 25(8):1775-1783

Yoon J, Cao X, Zhou Q, Ma LQ (2006) Accumulation of Pb, Cu, and $\mathrm{Zn}$ in native plants growing on a contaminated Florida site. Sci Total Environ 368(2-3):456-464

Zacchini M, Pietrini F, Mugnozza SG, Iori V, Pietrosanti L, Massacci A (2009) Metal tolerance, accumulation and trans location in poplar and willow clones treated with cadmium in hydroponics. Water Air Soil Pollut 197(1-4):23-34

Zhuang P, Shu W, Li Z, Liao B, Li J, Shao J (2009) Removal of metals by sorghum plants from contaminated land. J Environ Sci 21(10):1432-1437 